ISSN 2326-3350

\title{
Serum levels of Magnesium, Copper and Zinc in Young Couples
}

\author{
M.H. Salmani ${ }^{1,3^{*}}$, M. Vakili², M. Abedi ${ }^{3}$, S. A. Mozaffari ${ }^{3}$
}

Research Article

${ }^{1}$ Department of Environmental Health, Shahid Sadoughi University of Medical Science, Yazd, Iran.

${ }^{2}$ Department of Community Medicine, Shahid Sadoughi University of Medical Science, Yazd, Iran.

${ }^{3}$ Department of Chemical Technologies, Iranian Research Organization for Science \& Technology, Tehran, Iran.

\section{Abstract}

Metal ions are required for essential body functions but are toxic in excess. These have been examined critically as a potent factor in various human diseases including cardiovascular disease, cancer. This study was conducted to estimate the level of magnesium, copper and zinc in serum of young couples. The 60 young couples (30 males, 30 females) with the mean age $23.18 \pm 4.31$ years were included in this study. Serum elements level was measured using atomic absorption spectroscopy technique at calibration mode. The mean concentration of elements magnesium, copper and zinc in serum were $(26.93 \pm 3.83,1.61 \pm 0.31$ and $7.18 \pm 0.62 \mathrm{mg} / \mathrm{l})$ respectively. We observed the normal levels of magnesium, zinc, and copper in serum of young couples, as compared with normal range. The analysis of data was shown the dependency of serum concentration levels of magnesium, copper and zinc with age and sex.

Key Words: Copper Serum Concentration; Magnesium Serum Concentration; Zinc Serum Concentration; Metal Contents of Young Couples

\section{*Corresponding Author:}

M.H. Salmani

School of Health, Daneshjoo Blvd., Yazd. Iran.

Tel: +98913158 2878; Fax: 00983516238555

E-mail:mhsn06@yahoo.com

Received: December 26, 2013

Accepted: January 20, 2014

Published: January 21, 2014

Citation: M.H. Salmani, M. Vakili, M. Abedi, S. A. Mozaffari (2014) Serum levels of Magnesium, Copper and Zinc in Young Couples. Int J Food Sci Nutr Diet. 3(1), 85-88. doi: http://dx.doi.org/10.19070/23263350-1400017

Copyright: M.H. Salmani ${ }^{\circledR} 2014$ This is an open-access article distributed under the terms of the Creative Commons Attribution License, which permits unrestricted use, distribution and reproduction in any medium, provided the original author and source are credited.

\section{Introduction}

The maintenance of health requires an enough supply of proteins, carbohydrates and trace elements. Many trace elements present in trace quantities in human blood and play an essential role in a number of biological processes through their action as activators or inhibitors of enzymatic reactions, or through other functions. Hence, trace elemental assay in biological fluids can be used as diagnostic or prognostic aid in patients (Solomons 1993 and Sauberlich 1999). Two different subject areas of biological trace element research are nutritional essentiality and toxicity. Although copper, zinc and magnesium are essentially elements and has traditionally been regarded as relatively non-toxic, recent studies show that toxic effect has been observed with excessive element intake as a consequence of the use of various salts for pharmacological purposes.
Magnesium is the eighth most abundant element in the earth's crust. It does not occur as a pure metal in nature, but it is found in large deposits as magnesite, dolomite and other minerals. The magnesium content of water is variable. The concentration depends on the region of its source and its manner of storage. Hard water has a higher concentration of magnesium salts. Magnesium has an important function in many biochemical and physiological process, which directly effects human Lung function, asthma management, joint pain, smoothening of muscle function, neuromuscular excitability, immune function, inflammation, and oxidative stress (Prasad 1991). Research has shown that helps to regulate blood sugar levels and blood pressure (Vormann 2003). Magnesium is one of the most neglected mineral in human body that is required as a cofactor for many enzyme systems and is responsible for the activation of more than 300 enzymes in the body. It assists to maintain muscle and nerve function in human body. Magnesium deficiency has been linked to cardiovascular, skeletal, gastrointestinal and central nervous system disorders and hypocalcaemia is a common obvious of moderate to severe magnesium deficiency (Ryzen 1989). No adverse effects have been associated with the ingestion of magnesium as a naturally occurring substance in foods. However, harmful effects have been observed with excessive magnesium intake as a consequence of the use of various magnesium salts for medicinal purposes.

Copper is a common substance that occurs naturally in the environment and spreads through the environment. It can be released into the environment by both natural sources and human activities. Humans widely use copper in the industries and in agriculture. Then, Copper can be found in many kinds of food and drinking water that we absorb it by eating and drinking. The reception of copper is necessary, because it is a trace element that is required for cellular respiration, peptide amidation, neurotransmitter biosynthesis, pigment formation, and connective tissue strength. Al- 
though humans can handle proportionally large concentrations of copper, too much copper can still cause prominent health problems. Whether, carcinogenic of copper has not been determined yet. Long-term exposure to copper can cause irritation of the nose, mouth and eyes and it causes headaches, stomachaches, dizziness, vomiting and diarrhea. High uptakes of copper may cause liver and kidney damage and even death (Rinaldi 2000). Copper is one of many metal ions that are required for essential body functions but are toxic in excess (Solomons 1993 and Cai et al. 2005). Copper is a cofactor for numerous enzymes and plays an important role in central nervous system development. The low concentrations of copper may result in incomplete development, whereas excess copper may be adverse.

Zinc is extraordinarily useful in biological systems and plays specific catalytic, co-catalytic and structural roles in enzyme molecules, proteins and biomembranes (Hambidge 2003). It is involved in many biochemical processes and required for a kind of physiological functions including normal immune, sexual, neurosensory function. Zinc is an essential component of several proteins and metallo-enzymes including alkaline phosphatase, lactate dehyrogenase, carbonic anhydrase, carboxypeptides, and DNA and RNA polymerases found in most body tissues (Sullivan et al. 1979). Zinc is mainly required for DNA synthesis, cell division and protein synthesis. It has been hypothesized that Zinc could be operating at several different levels and influencing lymphocyte monoclonal proliferation (Hambidge et al. 1986). Zinc has important roles in thyroid metabolism (Dhawan et al. 2007) and a fundamental role in protein synthesis (Freake et al. 2001). Free zinc ions may be much more toxic biologically than is generally realized. The recent studies show that free zinc ions $\left(\mathrm{Zn}^{2+}\right)$ is a strong killer of neurons, glia and other cell types (Cai et al. 2005).

Several biomarkers can be considered to screen the concentration of elements in body. The content of blood elements is a useful biomarker and responds significantly to supplementation. For determination of elements in blood, usually the content of elements in serum or plasma is investigated (Li et al. 2012). In this study, for evaluation of the levels of some essential elements in young couples the concentration of magnesium, copper and zinc in blood serum has been determined by atomic absorption spectrometry.

\section{Material and Methods}

All glasswares were previously soaked in 10\% nitric acid and rinsed thoroughly with deionized water. This procedure was followed in order to exclude the possibility of contamination with trace elements. All chemicals were analytical grade and used without any purification. Stock solutions of $\mathrm{Zn}(\mathrm{II}), \mathrm{Cu}(\mathrm{II})$ and $\mathrm{Mg}(\mathrm{II})$ were prepared by dissolving appropriate amounts of $\mathrm{ZnSO}_{4} \cdot 7 \mathrm{H}_{2} \mathrm{O}$, $\mathrm{CuSO}_{4} \cdot 5 \mathrm{H}_{2} \mathrm{O}$ and $\mathrm{Mg}\left(\mathrm{NO}_{3}\right)_{2} \cdot 6 \mathrm{H}_{2} \mathrm{O}$ in $100 \mathrm{ml}$ distilled water in volumetric flasks. Working solutions for each element were prepared by diluting its stock solution.

Sixty volunteers comprising 30 males and 30 females (30 couples) having ages of 16-34 years from the Yazd city at center of Iran participated in this study. The healthy of subjects were diagnosed depending on the results of the GHQ28 questioner, only two males of them had score over of 23 and deleted to test. About $10 \mathrm{ml}$ of venous blood were drawn from blood taken who were referred for check up at the margin laboratory center by utilizing disposable plastic syringes in the morning. The blood samples were left to coagulate spontaneously and centrifuged at $4000 \mathrm{rpm}$ for 5 minutes at room temperature. The clean serum was sepa- rated and stored at $-20^{\circ} \mathrm{C}$ until analysis time.

One portion of samples was diluted to 10 (1:10) with 5\% 2-butanol solution. The concentrations of magnesium, copper and zinc in Serum samples were determined by direct measurement method using atomic absorption spectrophotometer (AA-20 Varian) in a suitable calibration curve for each element (Rothery 1990). Different concentrations $(0.5,1.0,2.0,5.0$ and $10.0 \mathrm{mg} / \mathrm{L})$ stock solutions of trace elements were used for calibration of standard graphs. The source of energy for atomization was air/ $\mathrm{C}_{2} \mathrm{H}_{2}$ flame at a flow rate of $6 / 1.8 \mathrm{~L} / \mathrm{min}$. Absorbances were recorded at $422.8 \mathrm{~nm}, 324.7 \mathrm{~nm}$ and $213.9 \mathrm{~nm}$ for magnesium, copper and zinc respectively in the atomic absorption spectrometer. A software package (SpactrAA software) was used to calculate concentrations of manganese, copper and zinc.

The measurements were replicated 3 times for each sample. The results were expressed as mean \pm SD by using SPSS (Windows Version 16) software. Differences between group means were determined by independent sample t-test. The significance level was set at $\mathrm{P}<0.05$.

\section{Results and Discussion}

This study was carried out to express the quantities of serum micronutrients in rural healthy couples of Yazd city in Iran. Their ages range of females and males rural couples were between 1634 years. In terms of education, they have $44.6 \%$ school education, $35.7 \%$ middle school and $19.6 \%$ lower levels. At first sixty volunteers comprising 30 males and 30 females (30 couples) were selected for study but as the healthy of subjects were diagnosed depending on the results of the GHQ28 questioner, and two males had score over of 23 , therefore deleted from the population of our study. Level of serum elements was calculated after application of absorbance on suitable calibration curve from standard solutions. The results of the study has been showed in Table (1) and indicates that the mean serum levels for magnesium, copper and zinc are respectively $27.30 \pm 3.83,1.61 \pm 0.31$ and $7.10 \pm$ $0.62 \mathrm{mg} / \mathrm{l}$, and in comparison with normal ranges, magnesium and zinc are in normal range but copper is near the normal range.

After potassium, Magnesium is the second most prevalent intracellular cation, and it has an important role as a cofactor in various enzymatic reactions and regulates various processes in the membrane. It also has a role in protein and DNA synthesis, and the regulation of mitochondrial function. The blood serum contents of magnesium are divided into three portions: $\mathrm{Mg}$ bound to proteins $(27 \%)$; in particular to albumin and to a lesser extent to globulins; ionized $\mathrm{Mg}(65 \%)$; and $\mathrm{Mg}$ complexes with anions $(8 \%)$ such as phosphate, bicarbonate, and citrate (Huijgen et al. 1996). Zinc and copper are micronutrients in human body and adjoin to proteins in biological systems and constitute metalloproteins. However, excessive quantities of zinc intake may lead to both acute and chronic toxicity. The recommended ranges for zinc intake are 5.5-9.5 mg/day for males and 4.0-7.0 mg/day for females. Nevertheless, excessive Zinc intake can have drastic effects and toxicity in humans. The case reports and experimental studies have indicated that the pancreas is the major target organ of Zinc toxicity (Madsen and Gitlin 2007). Copper is implicated directly or indirectly in the pathogenesis of numerous neurological diseases, including aceruloplasminemia, Alzheimer disease, amyotrophic lateral sclerosis, Huntington disease, Menkes disease, occipital horn syndrome, Parkinson disease, prion disease, and Wilson disease (Brown et al. 1964). Based on the important functions of these elements in body, the concentration of $\mathrm{Mg}, \mathrm{Cu}$ and 
Zn was investigated in rural young couples in Yazd city in Iran by atomic absorption spectrometry. For overcoming the serum viscosity (matrix viscosity) problems during determination of these elements by flame atomic absorption spectrometry, we used the 2-butanol-deionized water solution for diluting of standards and samples and to regular viscosity between standards and samples. Using the mixture of water : 2-butanol as solvent, decreases the viscosity of samples and helps the smaller droplet formation in nebulizer of atomic absorption and the efficiency of atomization increases (Meret and Henkin 1971).

For studying the influence of 2-butanol-water percents on the efficiency of atomization by atomic absorption spectroscopy, solutions with different percents $(3,4,5,6$ and $7 \%(\mathrm{v} / \mathrm{v})) 2$-butanol in water were examined on the absorption of one of the samples. The influence of different water : 2 - butanol percents on absorbance intensities of one serum sample has been shown in Figure
(1).

The results showed, the maximum absorbance intensity obtained at 5 percent 2-butanol in water as solvent, therefore all the samples diluted with $5 \%$ solution of 2 -butanol in water and their absorbances were measured. This method achieved 30\% increase in sensitivity as compared with using water only as diluents (Taylor and Bryant 1981). The validity of the accuracy of measurements was achieved by comprising the measurements data with standard addition values for zinc. The result of the comparison of two methods has been summarized in Table (2). As it seen, there are no significant differences between results obtained by two methods.

In our study, magnesium serum of females was higher than the males and zinc serum level of females are significantly lower than the males as shown in Table (1). However, the p-values correlations were 0.92 and 0.68 respectively and there was no significant

Table (1) Average concentrations of magnesium, copper and zinc and its standard deviations in blood serum of rural Yazd couples (ppm)

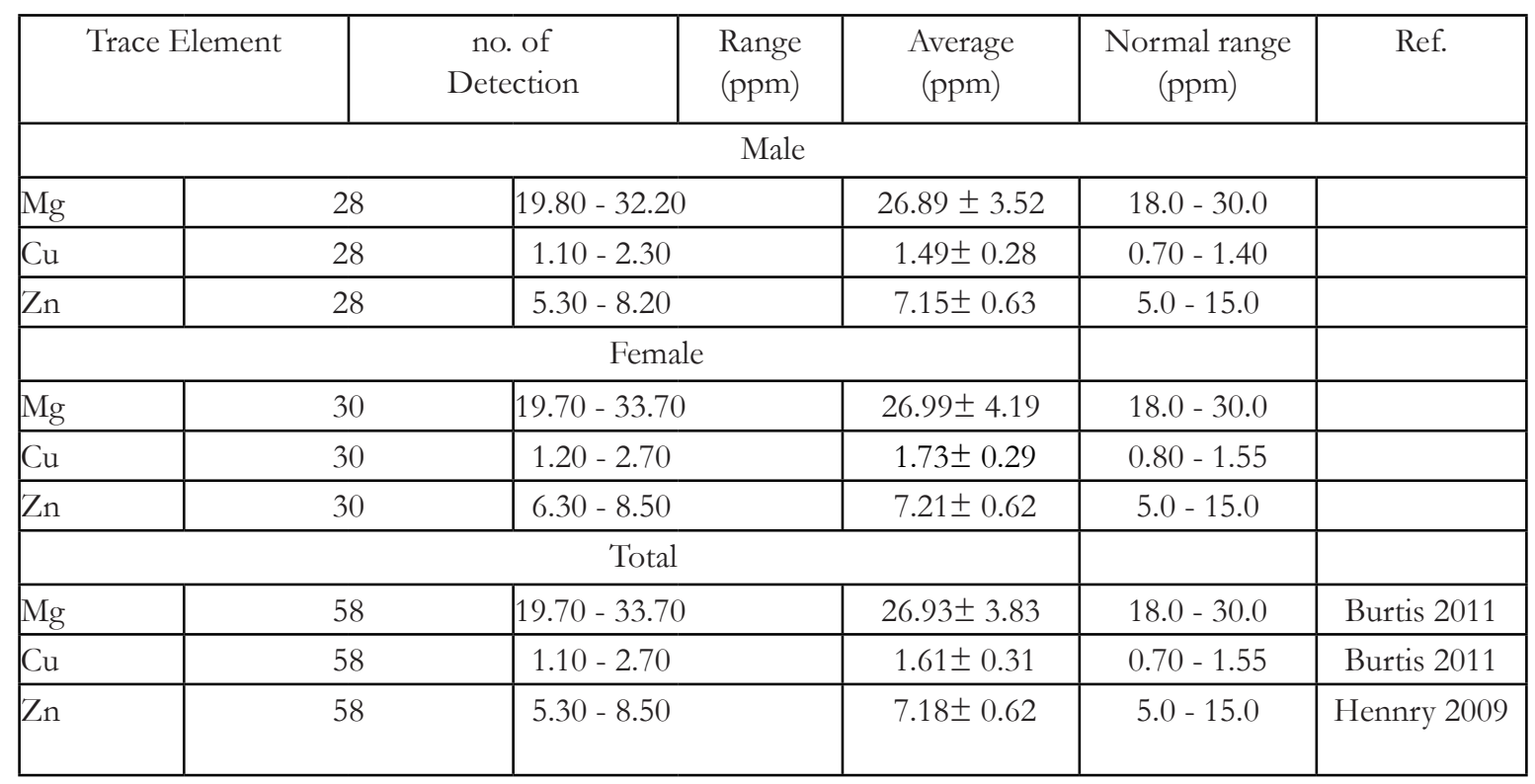

Figure 1. Effect of 2-botanol percent on the absorbance intensity of serum sample

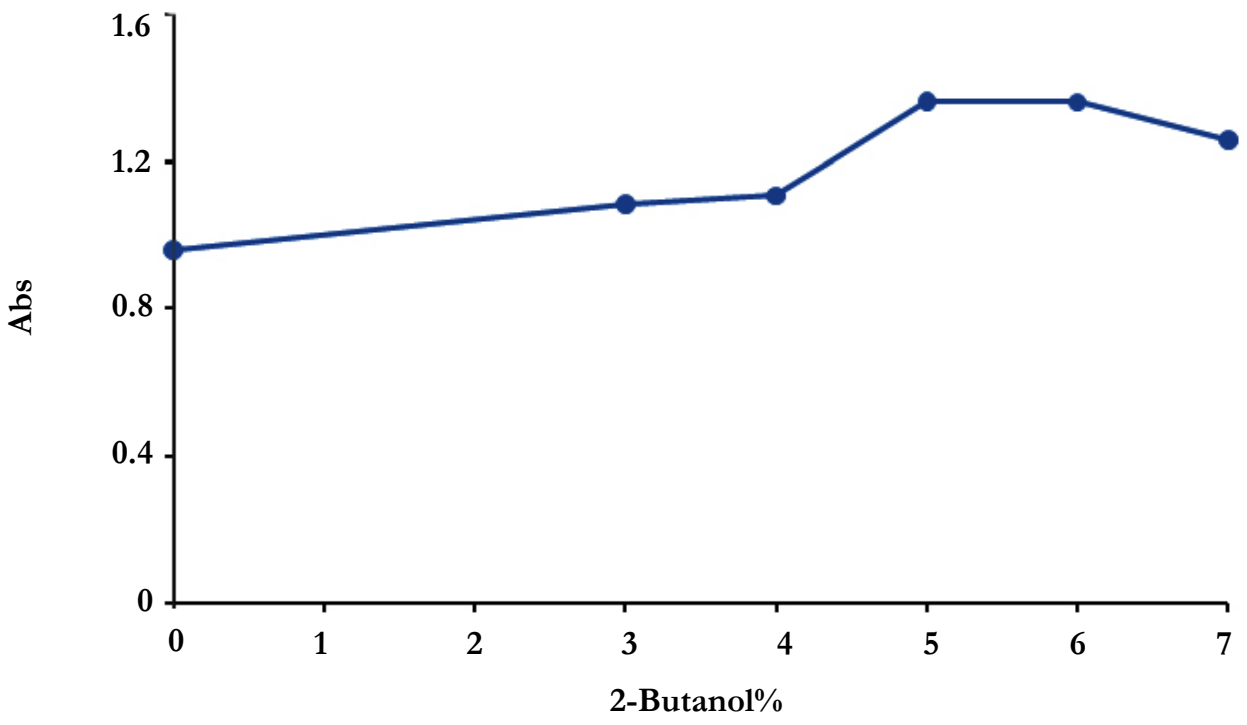


Table 2: Comparison the results of $\mathrm{Zn}$ serum concentrations by external standard and standard addition methods

\begin{tabular}{|c|c|c|c|}
\hline Sample & Standard addition & External standard & \multirow{2}{*}{ differences } \\
\cline { 1 - 3 } no & method & Method & 0.08 \\
\hline 1 & 6.82 & 6.9 & -0.02 \\
\hline 2 & 6.8 & 6.78 & 0.03 \\
\hline 3 & 7.09 & 7.12 & -0.01 \\
\hline 4 & 7.33 & 7.32 & 0.01 \\
\hline 5 & 8.15 & 8.16 & \\
\hline
\end{tabular}

correlation between magnesium and zinc levels with age. Our results confirm that the female's serum copper levels were higher than the males. The $\mathrm{p}$-value $=0.03$ showed that significant differences between the sexes were observed in the mean values but these mean values were in the range of normality.

\section{Competing Interests}

The author(s) declare that they have no competing interests.

\section{Author's Contributions}

M. Abedi and M.H. Salmani participated in the design of the study and drafted the manuscript. M.H. Salmani and M. Vakili collected the data, performed the statistical analysis. All authors read and approved the final manuscript.

\section{Acknowledgements}

This project was financially supported by the Faculty of Public Health, Shahid Sadoughi University of Medical Sciences. The authors express their appreciation to the Advanced Analytical Laboratory of Faculty of Public Health and Iranian Research organization for Science and Technology for cooperation in this work.

\section{References}

[1]. Burtis C., Ashwood E., and Burns D., (2011), Tietz Textbook of Clinical Chemistry and Molecular Diagnostics, 5th Edition, Washington DC.

[2]. Brown MA, Thom JV, Orth GL, et al. (1964), Food poisoning involving zinc contamination. Archive of Environmental Health 8, 657-660.

[3]. Cai L, Li XK, Song Y and Charian MG (2005) Essentiality, toxicology and chelation therapy of zinc and copper. Current Medical Chemistry12: 2753-2763.

[4]. Dhawan D., Singh Baweja M, and Dani V. (2007) Zinc sulfate following the administration of iodine-131 on the regulation of thyroid function, in rats. Hell Journal of Nuclear Medicine. 10(3):167-71.
[5]. Freake H.C., Govoni K.E., Guda K., Huang C., and Zinn S., (2001) Actions and interactions of thyroid hormone and zinc status in growing rats. Journal of Nutrition 131(4): 1135-1141.

[6]. Hambidge KM (2003), Biomarkers of trace mineral intake and status. Journal of Nutrition 133: 948S-955S.

[7]. Hambidge KM, Casey CE, Krebs NF. (1986) Zinc. In Mertz W., ed. traces elements in human and animal nutrition. Vol. 25 th ed. Orlando: Academic Press 1-137.

[8]. Hennry JB., (2009), Clinical and Management by Laboratory Method, 18th Edition WB Saunders.

[9]. Huijgen HJ, van Ingen HE, Kok WT., (1996) Magnesium fractions in serum of healthy individuals and CAPD patients, measured by an ion-selective electrode and ultra filtration. Clinical Biochemistry. 29; 261-266.

[10]. Li G., Brockman J.D., Lin S., Abnet C.C., Schell L.A., Robertson J.D., (2012) Measurement of the trace elements $\mathrm{Cu}, \mathrm{Zn}, \mathrm{Fe}$, and $\mathrm{Mg}$ and the ultratrace elements $\mathrm{Cd}, \mathrm{Co}, \mathrm{Mn}$, and $\mathrm{Pb}$ in limited quantity human plasma and serum samples by Inductively Coupled Plasma-Mass Spectrometry, American Journal of Analytical Chemistry, 3, 646-650.

[11]. Madsen E, Gitlin JD. (2007) Copper and iron disorders of the brain, Annual Review of Neuroscience; 30: 317-37.

[12]. Meret S. and Henkin K.I. (1971) Clin.Chem.17:369. Cited by: Gowenlock H.A., McMurray R.J., and McLauchlan M.D. 1988 Varly's Practical Clinical Biochemistry. 6th Ed., Heinemann Medical Books, London.

[13]. Prasad, A.S. (1991) Discovery of human Zn deficiency and studies in an experimental human model, American Journal of Clinical Nutrition, 53, 40312.

[14]. Rinaldi AC. (2000) Meeting report: copper research at the top. Biometals 13: $9-13$.

[15]. Rothery E. (1990) Analytical methods for atomic absorption, Varian instruments AA at Work. AA-93, Varian Australia Pty Ltd.

[16]. Ryzen E. (1989), Magnesium homeostasis in critically ill patients. Magnesium 8: 201-212.

[17]. Sauberlich HE. (1999) Laboratory tests for the assessment of nutritional status. Boca Raton, FL: CRC Press, 313.

[18]. Solomons N. (1993) Trace Elements in Clinical Nutrition: Parenteral Nutrition' 2nd edition, Philadelphia, USA pp. 150-183.

[19]. Sullivan F., Alan J., Blotcky, et al. (1979) Serum levels of selenium, calcium, copper, magnesium, manganese and zinc in various human diseases. Journal of Nutrition. 109, 1432-1437.

[20]. Taylor A. and Bryant T.N. (1981) Clin.Chim.Acta.110:83. Cited by: Gowenlock H.A., McMurray R.J. and Mclauchlan M.D. 1988 Varly's Practical Clinical Biochemistry. 6th Ed., Heinemann Medical Books, London.

[21]. Vormann, J. (2003). Magnesium: Nutrition and Metabolism. Molecular aspect of Medicine, 23, 27. 